\title{
ALK/TRK Inhibitor TSR-011
}

National Cancer Institute

\section{Source}

National Cancer Institute. ALKITRK Inhibitor TSR-011. NCI Thesaurus. Code C114287.

An orally available inhibitor of both the receptor tyrosine kinase anaplastic lymphoma kinase (ALK) and the tropomyosin-related kinases (TRK) TRKA, TRKB, and TRKC, with potential antineoplastic activity. Upon administration, ALK/T RK inhibitor TSR-011 binds to and inhibits both ALK and TRK kinases. The inhibition leads to disruption of ALK- and TRKmediated signaling and impedes tumor cell growth in ALK/T RK-overexpressing tumor cells. ALK belongs to the insulin receptor superfamily and plays an important role in nervous system development; ALK dysregulation and gene rearrangements are associated with a series of tumors. TRK, a family of receptor tyrosine kinases activated by neurotrophins, is mutated in a variety of cancer cell types and plays an important role in tumor cell growth and survival. 